\title{
THE STATE OF INTERNATIONAL RELATIONSHIP BETWEEN THE FORMATION AND ACTIVITY OF MOUNTAIN GLACES OF UZBEKISTAN
}

\section{Dr. Akmal R. Matnazarov}

Phd. Tashkent State Pedagogical University Department Of Geography Senior Lecturer, Uzbekistan Dr. Ural Kh. Safarov

Phd. Tashkent State Pedagogical University Department Of Geography Senior Lecturer, Uzbekistan Nasiba N.Hasanova

Master's Student, Tashkent State Pedagogical University Department Of Geography, Uzbekistan

\section{ABSTRACT}

This article describes the systematic study of the base surfaces in the formation and development of mountain glaciers of Uzbekistan and their current state.

KEYWORDS: - Glacier, deaf, trog, karling, slope, relief, base, base surface, Piskom, river, erosion, moraine nest, moraine lakes, glacial language.

\section{INTRODUCTION}

At the points noted, it is possible to observe the irregular scattering of large-sized erratic rocks along with paleomorenous mounds. All of this suggests that due to the large scale of the Paleomuzs in ancient times and the cold paleoclimate, the glaciers "fell" to the areas that covered the surfaces of the fourth order base at that time. Hence, it can be noted that these surfaces appear as accumulation zones of paleomuzs. The direct impact of mountain glaciers is clearly felt along the landscapes of the areas occupying the fourth-order base surfaces. These include low average annual temperatures, high rainfall, hydrological flow density, diversity of flora composition, and the presence of a separate area of rare species growing at high altitudes, such as akkayin, Turkestan spruce.

Basis surfaces are areas of accumulation of hydrological currents formed in accordance with the order of river erosion, rivers that form rivers. Therefore, the surfaces of the base (Latin for basis - Geological Dictionary, Volume I, 1955) 
CURRENT RESEARCH JOURNAL OF PEDAGOGICS 2(12): 22-25, December

2021 DOI: https://doi.org/10.37547/pedagogics-crjp-02-12-05

ISSN 2767-3278

(C)2021 Master Journals

Crossref do: 81 Google

Accepted 09th December, 2021 \& Published $14^{\text {th }}$ December, 2021

have different orders depending on how large the river valleys cover in different areas and how deep the erosion cuts have left. Glaciers also play an important role in the formation of these orders, especially at the points where cryogenic regions are present. Because the formation of hydrological flow is directly related to the presence of glaciers for such areas. Our map, "Peculiarities of Development of Mountain Glaciers in Uzbekistan along Base Surfaces," shows that there are four types of base surfaces for the Piskom, Surkhandarya, and Kashkadarya valleys. This means that mountain glaciers and their derivatives are formed in close connection with these base surfaces. This situation manifests itself in the form of a specific geomorphological pattern, and the areas where the processes of erosion, transport and accumulation of mountain glaciers occur are clearly distinguished by the order of the base surfaces.

\section{THE MAIN RESULTS AND FINDINGS}

The isobasites bordering the first-order base surfaces cover areas adjacent to high-altitude watersheds and watersheds, which are conducive to the formation of mountain glaciers, over which firn fields, tops of glaciers, and sometimes deaf-type glaciers are located. As mountain glaciers are actively developing erosion work across these areas, relief patterns formed under the influence of glacial erosion, such as ridges, deaf, carling, have been widely developed. This means that the first-order base surfaces are emerging as the main forming and actively developing areas of mountain glaciers. For this reason, it is distinguished by its richness of relief views formed due to mountain glaciers.

The second-order base surfaces form the middle parts of the surfaces and the deep erosion grooves - the main parts of the streams. The relief features typical for these regions, bordered by second-order isobasites, are so complex that the effects of neotectonic movements are clearly felt. However, against the background of tectonic movements, we can observe that the topography created by the activity of mountain glaciers also plays a leading role in the overall geomorphological structure of the region. In particular, the fact that the rivers often have a flat ridge - the beginning of the troughs, as well as the fact that the bottom of the trough valleys is covered with many moraine deposits - gives it a unique landscape.

Behind the mound of moraines are often accumulated water basins, which are characteristic of the upper parts of almost all trog valleys in the systematic form of small moraine lakes. Even in the recent geological periods, when paleocryogenic conditions prevailed throughout the region, it can be understood that the second-order areas of the base surfaces were involved as part of the active transport activities of mountain glaciers. This is because the trough valleys are composed of several stems, in which sometimes still longitudinally scattered moraine grooves further complicate the relief. For example, this situation has been repeatedly observed during our field observations along the upper reaches of the Onaolgansoy, Urungachsoy, Kaptarkumush, Badaqsay rivers.

The isobasite curve bounding the tertiary base surfaces ran along the lower parts of the mountains. Due to the fact that these areas are located far away from the geographical points where mountain glaciers exist today, glacial landscape landscapes along these areas are somewhat sparse. But their impact is still being felt. Traces left by paleomuzs in particular are common. These include the classically developed trough valleys, excursion tracks, trog caves, and sometimes even moraine mounds and moraine lakes that have survived along their bottoms.

The peculiarity is that we can understand that 
CURRENT RESEARCH JOURNAL OF PEDAGOGICS 2(12): 22-25, December

2021 DOI: https://doi.org/10.37547/pedagogics-crjp-02-12-05

ISSN 2767-3278

(C)2021 Master Journals

Crossref doi) 81 Google

Accepted 09th December, 2021 \& Published $14^{\text {th }}$ December, 2021

the volume of moraine mounds formed along the surfaces of the third-order base is several times larger than that of moraine mounds formed in the upper part of the valleys. We observed this situation during our field surveys in Bodoksay, Urungachsay and Ikhnachsay. As a result, the size of moraine lakes that suddenly formed during the increase in the size of moraine deposits also increases, and several large moraine lakes such as Upper Urungach (not Lower Urungach, because the Lower Urungach basin genetically belongs to the dam family), Bodak, Ikhnach were formed. Although all of these lakes have been recognized as dam lakes by A.M. Nikitin (1987), the results of our field research acknowledge that they belong to the group of moraine lakes. This is because the huge moraine deposits brought by the Paleomoids blocked the Bodoksay, Urungachsay, and Ikhnachsay rivers, and large reservoirs were formed behind them.

The current is flowing along the granular moraine deposits. In particular, the scale of the Paleomoids, formed in the upper reaches of the Bodoksay, Urungachsay, Ikhnachsay, reaching their middle reaches, shows how large their current state is, and the fact that modern mountain glaciers are located only along the first order of the base, and in ancient times covered the second and third orders. and indicates that these areas formed the transport and accumulation areas of the Paleomoids. Epigenetic valleys are sometimes formed in these areas. Because moraine mounds block the valley, the stream has carved out rocky layers on the side and a new stream has formed. These cases are characteristic of cryogenic regions, emphasizing that they play an important role in the geomorphological structure of the region, as well as their distribution on the basis of natural geomorphological laws.

The surfaces of the fourth order base cover the lower parts of the lateral rivers, the areas that form their points of confluence with the Oygaing,
Kashkadarya, Topolangdarya. Traces of glacial processes are very rare in these areas. In particular, at the confluence of the rivers Maidontol, Turtogayni, Beshtor, Koksuv, Tekesh to the Moon, and even in the Sarijoyak plain, which is formed at the confluence of the river Oygaing and the River Maidontol, the accumulative activity of paleomuzs is clearly visible.

\section{REFERENCES}

1. Baratov P. Natural geography of Uzbekistan - T .: "Teacher", 1996, 263 p.

2. Geological Dictionary. State Scientific tech. Publishing house of literature on geology and protection of mineral resources. M.,

3. 1955 Ni A.A. and others. Degradation of the Tekishsay-1 glacier After the Little Ice Age. Proceedings of SANIGMI 1994, vip. 147 (228) pp. 153-155.

4. Низомов А, Нугманова А, Матназаров А. Ўзбекистон тоғ музликлари - Тошкент “Фан ва технология" 2016, 98 б.

5. Shchetinnikov A.S. Glaciers of the Pskem river basin. L.: Leningrad, Gidrometizdat, $1976.120 \mathrm{p}$.

6. Khojamkulov B.E., Choriev R.R., Rakhimov A.L., Omonov O.E. On the history of studying the flora of Kashkadarya // QarSU news 1 (23). 2015. Pages 40 - 45.

7. Rasulov, A. B. (2020). GEOECOLOGICAL ASPECTS OF SUSTAINABLE DEVELOPMENT. In SCIENCE AND EDUCATION: PROBLEMS AND INNOVATIONS (pp. 307-310).

8. Nigmatov A.N., Abdireimov S.J., Rasulov A., Bekaeva M.E. Experience of using gis 
CURRENT RESEARCH JOURNAL OF PEDAGOGICS 2(12): 22-25, December

2021 DOI: https://doi.org/10.37547/pedagogics-crjp-02-12-05

ISSN 2767-3278

(C)2021 Master Journals

Crossref doi) 81 Google

Accepted 09th December, 2021 \& Published 14th December, 2021

technology in the development of geoecological maps // International Journal of Engineering Research and Technology 13. № 12. 4835-4838 p.

9. Rasulov, A. B., \& Rasulova, N. A. (2020). METHODOLOGY OF GEOECOLOGICAL INDICATORS OF SUSTAINABLE DEVELOPMENT, GLOBAL GEOECOLOGICAL INDICATORS. In COBPEMEHНЫЕ НАУЧНЫЕ ИССЛЕДОВАНИЯ: АКТУАЛЬНЫЕ ВОПРОСЫ, ДОСТИЖЕНИЯ И ИННОВАЦИИ (рр. 302-305).

10. Rasulov, A. B. (2020). GEOECOLOGICAL ASPECTS OF SUSTAINABLE DEVELOPMENT. In SCIENCE AND EDUCATION: PROBLEMS AND INNOVATIONS (pp. 307-310).

11. Odilov, B. A., \& Karimov, N. R. (2020). Analysis of Targeted Research in 20-30 Years of the XX Century. PalArch's Journal of Archaeology of Egypt/Egyptology, 17(6), 8887-8893. 